\title{
PENGARUH PEMBERIAN ZAT BESI DAN SAYUR BAYAM TERHADAP PENINGKATAN KADAR HEMOGLOBIN IBU HAMIL DENGAN ANEMIA DI WILAYAH KERJA PUSKESMAS MARTAPURA I
}

\author{
Yenny Okvitasari ${ }^{1}$, Darmayanti ${ }^{2}$, Maria Ulfah ${ }^{3}$ \\ 1,2,3 Universitas Muhammadiyah Banjarmasin \\ Email:okvitasariyenny@gmail.com
}

\begin{abstract}
Anemia of pregnancy is a condition in which the mother has a hemoglobin level below $11 \mathrm{~g} / \mathrm{dl}$ in the first and third trimesters or a hemoglobin level \&lt; $10.5 \mathrm{~g} / \mathrm{dl}$ in the second trimester. Spinach is one of the sources of food that contains compounds needed for the synthesis of hemoglobin such as iron. The purpose of the study was to determine the difference in the effect of giving iron and spinach with iron on increasing hemoglobin levels of pregnant women with anemia. The research method was Quasi Experiment using Paired T-test and Independent T-test, the research sample used 30 respondents by purposive sampling with inclusion and exclusion criteria. The results of the study were conducted on 30 respondents who were divided into two intervention groups and a control group for 14 days. Before being given iron, the mean value was $9,6 \mathrm{~g} / \mathrm{dl}$ and hemoglobin levels after iron was given an average value of $10.8 \mathrm{~g} / \mathrm{dl}$, during administration the average change in hemoglobin in pregnant women in the intervention group was $1.43 \mathrm{~g} / \mathrm{dl}$ and in the control group $1.17 \mathrm{~g} / \mathrm{dl}$. Independent T-test results obtained p-value 0.001 value (<0.05) which means that there is a difference in the effect between the intervention and control groups with a difference of $0.26 \mathrm{~g} / \mathrm{dl}$ value. Suggestions for pregnant women who experience anemia can consume iron added with additional food spinach vegetables.
\end{abstract}

Keywords: Iron, Spinach, Hemoglobin Levels, Pregnant Women

\begin{abstract}
ABSTRAK
Anemia kehamilan adalah kondisi ibu dalam kadar hemoglobin dibawah $11 \mathrm{~g} / \mathrm{dl}$ pada trimester I dan III atau kadar hemoglobin < 10,5 g/dl pada trimester II. Bayam merupakan salah satu sumber makan yang mengandung senyawa yang diperlukan untuk sintesis hemoglobin seperti zat besi. Tujuan penelitian untuk mengetahui perbedaan pengaruh pemberian zat besi dan sayur bayam dengan zat besi terhadap peningkatan kadar hemoglobin ibu hamil dengan anemia. Metode penelitian Quasi Eksperimen dengan menggunakan Uji Paired T-test dan Uji Independent T-test, sampel penelitian menggunakan 30 responden secara Purposive Sampling dengan kriteria inklusi dan eksklusi. Hasil penelitian dilakukan pada 30 responden yang dibagi menjadi dua kelompok intervensi dan kelompok kontrol selama 14 hari. Sebelum diberikan zat besi didapatkan nilai rerata 9,6 g/dl dan kadar hemoglobin sesudah diberikan zat besi didapatkan nilai rerata $10,8 \mathrm{~g} / \mathrm{dl}$, selama pemberian didapatkan rerata perubahan hemoglobin pada ibu hamil kelompok intervensi sebesar 1,43 g/dl dan pada kelompok kontrol 1,17 g/dl. Hasil Uji Independent T-test didapatkan p-value 0,001 nilai $\alpha(<0,05)$ yang artinya ada perbedaan pengaruh antara kelompok intervensi dan kontrol dengan selisih nilai 0,26 g/dl. Saran untuk ibu hamil yang mengalami anemia dapat mengkonsumsi zat besi ditambah dengan makanan tambahan sayur bayam.
\end{abstract}

Kata Kunci: Zat besi, bayam, kadar hemoglobin, ibu hamil

\section{Pendahuluan}

Anemia dalam dalam kehamilan adalah kondisi ibu dalam kadar hemoglobin dibawah $11 \mathrm{~g} / \mathrm{dl}$ pada trimester I dan III atau kadar hemoglobin < 10,5 g/dl pada trimester II (Proverawati, 2011). Anemia pada kehamilan merupakan masalah nasional karena mencerminkan kesejahteraan sosial ekonomi masyarakat dan pengaruh besar terhadap kualitas sumber daya manusia. Anemia kehamilan disebut "potential danger to mother and child" (potensi membahayakan ibu dan anak), karena itulah anemia memerlukan perhatian serius dari semua pihak yang terkait dalam pelayanan kesehatan (Manuaba, 2010). World Health Organization (WHO) tahun 2010 menyebutkan bahwa $40 \%$ penyebab kematian ibu di negara berkembang berkaitan dengan anemia dalam kehamilan. Anemia dalam kehamilan merupakan masalah kesehatan yang utama di negara berkembang dengan tingkat kesakitan tinggi pada 
ibu hamil. Total penderita anemia pada ibu hamil di Indonesia adalah $70 \%$, artinya dari $10 \mathrm{ibu}$ hamil, sebanyak 7 orang akan menderita anemia. Data Riset Kesehatan Dasar pada tahun 2013 menunjukkan, prevalensi anemia ibu hamil di Indonesia sebesar $37 \%$ mengalami peningkatan dari tahun 2007 sebanyak 24,5\% (Kemenkes RI, 2014).

Tingginya prevalensinya anemia pada ibu hamil merupakan masalah yang tengah dihadapi pemerintah Indonesia. Kejadian anemia pada ibu hamil dari tahun 2013 didapatkan 31,7\% dan angka kejadian anemia tersebut semakin tahun semakin meningkat, sampai 2018 anemia pada ibu hamil didapatkan 48,9\% (Riskesdas, 2018).

Ibu hamil yang mengkonsumsi zat besi akan mengalami beberapa efek samping seperti mual, muntah, konstipasi dan nyeri ulu hati. Hasil penelitian di desa Sidemen Karangasem ditemukan dari 50 orang ibu hamil mengkonsumsi tablet zat besi, 32 orang ibu hamil tidak patuh dalam mengkonsumsi tablet zat besi. Hal ini dikarenakan oleh efek samping yang dirasakan ibu hamil ketika mengkonsumsi tablet zat besi. Penelitian ini sejalan juga dengan pendapat Hidayah dan Anasari (2012). Lebih lanjut suplemen zat oral besi dapat menyebabkan mual, muntah, nyeri ulu hati dan konstipasi (Yanti, 2018).

Salah satu alternatif untuk memenuhi kebutuhan zat besi dapat dilakukan dengan mengkonsumsi sayuran yang berwarna hijau, salah satunya bayam. Zat besi yang terkandung didalam bayam sangat tinggi sebesar 3,9 mg / 100 gram (Merlina, 2016). World Health Organization (WHO) dalam Rohmatika (2016) menuliskan bahwa kebijakan pemerintah dalam menangani masalah anemia dalam kehamilan adalah dengan pemberian suplementasi besi dan asam folat. Fatimah (2009) dalam Rohmatika (2016) menunjukkan bahwa salah satu alternatif untuk memenuhi kebutuhan zat besi dapat dilakukan dengan konsumsi sayuran yang mengandung zat besi dalam menu makanan. Zat besi ditemukan pada sayur-sayuran, antara lain bayam (Amaranthus spp). Sayuran berhijau daun seperti bayam adalah sumber besi non-heme. Bayam yang telah dimasak mengandung zat besi sebanyak 8,3 mg/100 gram. Menambahkan zat besi pada bayam berperan untuk pembentukan hemoglobin.
Bayam hijau memiliki banyak manfaat yang sangat baik karena merupakan sumber kalsium, vitamin A, Vitamin C, dan Vitamin E, serat dan juga betakaroten. Selain itu bayam juga memiliki kandungan zat besi yang sangat tinggi untuk mencegah anemia. Kandungan mineral dalam bayam cukup tinggi, terutama zat besi dalam bayam cukup tinggi ditambah kandungan vitamin B terutama asal folat (Rohmatika, 2017).

Hasil penelitian yang dilakukan oleh Rohmatika et al (2016) yang dilakukan pada 34 responden yang terdiri dari kelompok I (ekstrak bayam hijau) dan kelompok II (tablet Fe) selama 7 hari. Selama suplementasi rata-rata perubahan kadar hemoglobin pada ibu hamil kelompok I sebesar $0,541 \mathrm{gr} / \mathrm{dl}$ dan pada kelompok II sebesar 0,22 $\mathrm{gr} / \mathrm{dl}$. Hasil uji Non parametrik Mann Whitney test didapatkan ada pengaruh konsumsi ekstrak bayam hijau terhadap perubahan kadar haemoglobin dengan $p$ value 0.038 yang artinya pemberian ekstrak bayam hijau secara signifikan mempengaruhi perubahan kadar haemoglobin.

Data yang diperoleh dari Puskesmas Martapura 1 dari bulan januari sampai dengan bulan juni menunjukkan 1.895 (100\%) ibu hamil, dan 333 $(17,57 \%)$ Ibu hamil yang mengalami anemia pada kehamilan. Pada studi pendahuluan yang dilakukan pada $10 \mathrm{ibu}$ hamil yang mengalami anemia pada kehamilan, sebanyak 7 orang yang mengalami anemia dengan kadar hemoglobin rata-rata $<11 \mathrm{~g} / \mathrm{dl}$, dan biasanya ibu hanya meminum obat tablet zat besi saja tidak didampingi makanan khusus yang dapat meningkatkan hemoglobin terutama bayam hijau.

\section{Metode}

Penelitian ini menggunakan metode Quasi Eksperimen yang menggunakan pendekatan atau rancangan Two Group Pretest Posttest design Non Equivalent. Penelitian ini dilakukan dengan cara memberikan pretest (pengamatan awal) terlebih dahulu sebelum diberikan intervensi. Setelah itu diberikan intervensi, kemudian dilakukan posttest (pengamatan akhir). Sampel dalam penelitian ini adalah 30 yang dibagi menjadi dua kelompok yaitu kelompok intervensi dan kelompok kontrol ibu hamil dengan anemia di Wilayah Kerja Puskesmas Martapura 1. 


\section{Hasil Penelitian}

\section{A. Karakteristik Responden}

Tabel 1. Distribusi karakteristik responden berdasarkan usia di Wilayah Kerja Puskesmas Martapura 1.

\begin{tabular}{|c|c|c|c|c|}
\hline \multirow[t]{2}{*}{$\begin{array}{c}\text { Usia } \\
\text { (tahun) }\end{array}$} & \multicolumn{2}{|c|}{$\begin{array}{l}\text { Kelompok } \\
\text { intervensi }\end{array}$} & \multicolumn{2}{|c|}{$\begin{array}{r}\text { Kelompok } \\
\text { kontrol }\end{array}$} \\
\hline & $f$ & $\%$ & $f$ & $\%$ \\
\hline $20-30$ & 10 & 66,7 & 11 & 73,3 \\
\hline $31-35$ & 5 & 33,3 & 4 & 26,7 \\
\hline Total & 15 & 100 & 15 & 100 \\
\hline
\end{tabular}

Tabel. 1 menunjukkan bahwa pada kelompok intervensi dan control, sama-sama usia responden terbanyak di usia 20-30 tahun pada kelompok intervensi sebanyak $10 \quad(66,7 \%)$ orang dan kelompok kontrol sebanyak $11 \quad(73,3 \%)$ orang.

Tabel 2. Distribusi karakteristik responden berdasarkan pendidikan di Wilayah Kerja Puskesmas Martapura 1.

\begin{tabular}{lcccc}
\hline Pendidikan & \multicolumn{2}{c}{$\begin{array}{c}\text { Kelompok } \\
\text { intervensi }\end{array}$} & \multicolumn{2}{c}{$\begin{array}{c}\text { kelompok } \\
\end{array}$} \\
\cline { 2 - 5 } & F & $\%$ & f & $\%$ \\
\hline Dasar & 14 & 93,3 & 11 & 73,3 \\
Menengah & 1 & 6,7 & 4 & 26,7 \\
\hline Total & 15 & 100 & 15 & 100 \\
\hline
\end{tabular}

Tabel 2. menunjukkan bahwa pada kelompok intervensi pada karakteristik pendidikan yang terbanyak adalah pendidikan dasar yaitu sebanyak $14(93,3 \%)$ orang dan pada kelompok kontrol pada karakteristik pendidikan terbanyak adalah pendidikan dasar yaitu sebanyak $11 \quad(73,3 \%)$ orang.
Tabel.3 Distribusi karakteristik responden berdasarkan pekerjaan di Wilayah Kerja Puskesmas Martapura 1.

\begin{tabular}{lrrrrr}
\hline Pekerjaan & \multicolumn{2}{c}{$\begin{array}{c}\text { Kelompok } \\
\text { intervensi }\end{array}$} & \multicolumn{3}{c}{ Kelompok kontrol } \\
\cline { 2 - 6 } & f & \% & & f & \% \\
\hline Swasta & 9 & 60 & 6 & 40 \\
Dagang & 5 & 33,3 & 3 & 20 \\
IRT & 0 & 0 & 6 & 40 \\
Petani & 1 & 6,7 & 0 & 0 \\
& & & & & \\
\hline Total & 15 & 100 & 15 & 100 \\
\hline
\end{tabular}

Tabel. 3 diatas dapat dilihat dari kelompok intervensi lebih banyak ibu hamil bekerja sebagai swasta yaitu sebanyak 9 (60\%) sedangkan pada kelompok kontrol lebih banyak ibu hamil yang bekerja swasta yaitu sebanyak $6(40 \%)$ orang dan jadi IRT yaitu sebanyak 6 (40\%) orang.

\section{B. Analisa Univariat}

Tabel.4 Kadar hemoglobin sebelum dan sesudah diberikan zat besi dan sayur bayam pada kelompok intervensi ibu hamil dengan anemia di Wilayah Kerja Puskesmas Martapura 1.

\begin{tabular}{|c|c|c|c|}
\hline $\begin{array}{l}\text { Kelompok } \\
\text { intervensi }\end{array}$ & $\begin{array}{l}\text { Mean } \\
\text { (g/dl) }\end{array}$ & $\begin{array}{l}\text { Nilai } \\
\text { minimal } \\
(\mathrm{g} / \mathrm{dl})\end{array}$ & $\begin{array}{l}\text { Nilai } \\
\text { Maksimal } \\
\text { (g/dl) }\end{array}$ \\
\hline Sebelum & 9,55 & 9,10 & 9,90 \\
\hline $\begin{array}{ll}\text { Sesudah } & (14 \\
\text { hari) } & \end{array}$ & 10,98 & 10,50 & 11,50 \\
\hline
\end{tabular}

Tabel.4 menunjukkan bahwa kadar hemoglobin pada kelompok intervensi sebelum diberikan zat besi dan sayur bayam didapatkan nilai rerata 9,55 $\mathrm{g} / \mathrm{dl}$ dan kadar hemoglobin sesudah diberikan zat besi dan sayur bayam didapatkan nilai rerata $10,98 \mathrm{~g} / \mathrm{dl}$.

Tabel.5 Kadar hemoglobin sebelum dan sesudah diberikan zat besi pada kelompok kontrol ibu hamil dengan anemia di Wilayah Kerja Puskesmas Martapura 1

\begin{tabular}{|c|c|c|c|}
\hline $\begin{array}{l}\text { Kelompok } \\
\text { intervensi }\end{array}$ & $\begin{array}{l}\text { Mean } \\
(g / d l)\end{array}$ & $\begin{array}{l}\text { Nilai } \\
\text { minimal } \\
(\mathrm{g} / \mathrm{dl})\end{array}$ & $\begin{array}{l}\text { Nilai } \\
\text { Maksimal } \\
\text { (g/dl) }\end{array}$ \\
\hline Sebelum & 9,69 & 9,50 & 9,90 \\
\hline $\begin{array}{l}\text { Sesudah } \\
\text { hari) }\end{array}$ & 10,86 & 10,50 & 11,20 \\
\hline
\end{tabular}


Tabel.5 menunjukkan bahwa kadar hemoglobin pada kelompok kontrol sebelum diberikan zat besi didapatkan nilai rerata 9,69 g/dl dan kadar hemoglobin sesudah diberikan zat besi didapatkan nilai rerata $10,86 \mathrm{~g} / \mathrm{dl}$.

\section{Analisa Bivariat}

Tabel.6 Hasil uji normalitas Shapiro-wilkdata sampel kelompok intervensi.

\begin{tabular}{cccc}
\hline & \multicolumn{3}{c}{ Shapiro-Wilk } \\
& Statistik & df & Sig. \\
\hline $\begin{array}{c}\text { Kadar HB (Pre) } \\
\text { kelompok }\end{array}$ & .972 & 15 & 0,891 \\
$\begin{array}{c}\text { intervensi } \\
\text { Kadar HB (Post) } \\
\text { kelompok } \\
\text { intervensi }\end{array}$ & .966 & 15 & 0,789 \\
\hline
\end{tabular}

Tabel.6 menunjukan hasil uji Shapiro-wilk. Nilai $p$-value (sig) pada kelompok pre $0,891(\alpha>0,05)$ dan nilai $p$-value (sig) pada kelompok post yaitu $0,789(\alpha>0,05)$. Karena semua data $>0,05$ maka kedua data berdistribusi normal berdasarkan uji Shapiro-Wilk.

Tabel.7 Hasil uji normalitas Shapiro-wilk data sampel kelompok kontrol.

\begin{tabular}{lccc}
\hline & \multicolumn{3}{c}{ Shapiro-Wilk } \\
& Statistik & df & Sig. \\
\hline $\begin{array}{l}\text { Kadar HB (Pre) } \\
\text { kelompok kontrol }\end{array}$ & .895 & 15 & 0.080 \\
$\begin{array}{l}\text { Kadar HB (Post) } \\
\text { kelompok kontrol }\end{array}$ & .932 & 15 & 0.288 \\
\hline
\end{tabular}

Tabel.7 menunjukan hasil uji Shapiro-wilk. Nilai $p$-value (sig) pada kelompok pre 0,080 $(\alpha>0,05)$ dan nilai $p$-value (sig) pada kelompok post yaitu $0,288(\alpha>0,05)$. Karena semua data $>0,05$ maka kedua data berdistribusi normal berdasarkan uji Shapiro-Wilk.

Tabel.8 Analisis perbedaan kadar hemoglobin sebelum dan sesudah diberikan zat besi dan sayur bayam pada kelompok intervensi ibu hamil dengan anemia di Wilayah Kerja Puskesmas Martapura 1

\begin{tabular}{lcrrr}
\hline Variabel & F & Mean & $\begin{array}{c}\text { Std. } \\
\text { Deviation }\end{array}$ & P-Value \\
\hline Sebelum & 15 & 9,55 & 0,213 & 0,000 \\
Sesudah & 15 & 10,98 & 0,276 & \\
& & & & \\
\hline
\end{tabular}

Tabel.8 menunjukan analisis kadar hemoglobin sebelum dan sesudah diberikan zat besi dan sayur bayam pada kelompok intervensi dengan hasil $U j i$ Paired T-test didapatkan nilai signifikan pengaruh yaitu 0,000 yang artinya nilai $\alpha(<0,05)$ maka dapat disimpulkan bahwa terdapat pengaruh pemberian zat besi dan sayur bayam terhadap peningkatan kadar hemoglobin.

Tabel.9 Analisis perbedaan kadar hemoglobin sebelum dan sesudah diberikan zat besi pada kelompok kontrol ibu hamil dengan anemia di Wilayah Kerja Puskesmas Martapura 1.

\begin{tabular}{lrrrr}
\hline Variabel & F & Mean & \multicolumn{1}{c}{$\begin{array}{c}\text { Std. } \\
\text { Deviation }\end{array}$} & P-Value \\
\hline Sebelum & 15 & 9,69 & 0,122 & 0,000 \\
Sesudah & 15 & 10,86 & 0,184 & \\
\hline
\end{tabular}

Tabel.9 menunjukan analisis kadar hemoglobin sebelum dan sesudah diberikan zat besi pada kelompok kontrol dengan hasil Uji Paired T-test didapatkan nilai signifikan pengaruh yaitu 0,000 , yang artinya nilai $\alpha(<0,05)$ dapat disimpulkan bahwa terdapat pengaruh pemberian zat besi terhadap peningkatan kadar hemoglobin.

Tabel.10 Analisis perbedaan kadar hemoglobin pada kelompok intervensi dan kelompok kontrol ibu hamil dengan anemia di Wilayah Kerja Puskesmas Martapura 1

\begin{tabular}{lccccc}
\hline Kelompok & $\mathrm{f}$ & $\begin{array}{c}\text { Mean } \\
\text { Rank }\end{array}$ & $\begin{array}{c}\text { Standa } \\
\mathrm{r} \\
\text { devias } \\
\mathrm{i}\end{array}$ & $\begin{array}{c}\text { Selisih } \\
\text { mean }\end{array}$ & $\begin{array}{c}p \text { - } \\
\text { value }\end{array}$ \\
\hline Intervensi & 15 & 1,43 & 0,179 & \\
Kontrol & 15 & 1,17 & 0,188 & 0,26 & 0,001 \\
\hline
\end{tabular}

Tabel.10 menunjukkan analisis perbedaan kadar hemoglobin pada kelompok intervensi dan kelompok kontrol dengan hasil uji Independent $T$ test didapatkan nilai signifikan $p$-value 0,001 yang artinya nilai $\alpha(<0,05)$. Hasil ini menyimpulkan ada perbedaan pengaruh pada kelompok intervensi dan kelompok kontrol dalam perubahan kadar hemoglobin.

\section{PEMBAHASAN}

Responden yang diteliti berjumlah 30 orang yang dibagi menjadi dua kelompok intervensi dan kelompok kontrol selama 14 hari. Selama 
pemberian didapatkan rerata perubahan hemoglobin pada ibu hamil kelompok intervensi sebesar 1,43 g/dl dan pada kelompok kontrol 1,17 g/dl. Hasil Uji Independent T-test didapatkan pvalue 0,001 nilai $\alpha(<0,05)$ yang artinya ada perbedaan pengaruh antara kelompok intervensi dan kontrol dengan selisih nilai 0,26 g/dl. Kadar hemoglobin pada kelompok intervensi sebelum diberikan zat besi dan sayur bayam didapatkan nilai rerata 9,55 $\mathrm{g} / \mathrm{dl}$ dan kadar hemoglobin sesudah diberikan zat besi dan sayur bayam didapatkan nilai rerata $10,98 \mathrm{~g} / \mathrm{dl}$.

Anemia dalam kehamilan adalah kondisi ibu dalam kadar $\mathrm{HB}$ dibawah $11 \mathrm{~g} / \mathrm{dl}$ pada trimester I dan III atau kadar $\mathrm{HB}<10,5 \mathrm{~g} / \mathrm{dl}$ pada trimester II. (Proverawati, 2011). Biasanya pada ibu hamil dengan anemia diberikan preparat zat besi sebesar $60 \mathrm{mg}$ asam folat $0.40 \mathrm{mg}$ selama 30 hari dapat meningkatkan kadar HB sebanyak 1 gram untuk pemberian 1 x sehari. (Saifuddin, 2010). Zat besi juga ditemukan dalam sayur-sayuran antara lain bayam, Sayuran berhijau daun seperti bayam adalah sumber besi non heme. Bayam yang telah dimasak mengandung zat besi sebanyak 8,3 mg/100 gram. Menambahkan kandungan zat besi pada bayam berperan untuk pembentukan hemoglobin. (Rohmatika, 2017).

Bayam hijau (Amaranthus spp) merupakan salah satu sumber makanan yang mengandung senyawa yang diperlukan dalam sintesis hemoglobin seperti zat besi dan vitamin B kompleks, maka dari itu salah satu alternatif untuk memenuhi kebutuhan zat besi dapat dilakukan dengan mengkonsumsi bayam hijau yang mengandung zat besi dalam menu makanan (Rohmatika,2017). Sehingga ibu hamil yang mengkonsumsi tablet zat besi dan sayur bayam dapat meningkatkan kadar hemoglobin dan dapat dilihat dari kelompok intervensi tersebut ada yang awalnya mengalami anemia ringan dari 15 responden ada 7 responden yang sudah tidak mengalami anemia. Dengan ini dapat disimpulkan bahwa tablet zat besi dan sayur bayam ini mampu meningkatkan kadar hemoglobin pada ibu hamil.

Kadar hemoglobin pada kelompok kontrol sebelum diberikan zat besi didapatkan nilai rerata 9,69 g/dl dan kadar hemoglobin sesudah diberikan zat besi didapatkan nilai rerata 10,86 g/dl. Tablet zat besi merupakan tablet mineral yang diperlukan oleh tubuh untuk membentuk sel darah merah atau hemoglobin. Unsur zat besi merupakan unsur paling penting untuk pembentukan sel darah merah. Tablet zat besi sangat dibutuhkan oleh ibu hamil sehingga diharuskan untuk mengkonsumsi tablet zat besi minimal sebanyak 60 tablet selama kehamilan. (Kemenkes RI, 2018).

Nugrahani (2013) menunjukkan bahwa asupan nutrisi berupa zat besi sangat mempengaruhi kadar Hemoglobin dalam darah. Sumber makanan yang mengandung banyak zat besi adalah hewani terutama pada hati yang merupakan tempat paling banyak mengandung zat besi (antara 6,0 mg sampai 14,0 mg). Sehingga dengan demikian mengkonsumsi tablet zat besi dapat meningkatkan kadar hemoglobin dalam darah. Dapat dilihat dari hasil ditemukan dari 15 responden ada 5 responden yang awalnya mengalami anemia ringan menjadi tidak anemia lagi yang artinya memang tablet zat besi ini mampu menaikan kadar hemoglobin dalam darah pada ibu hamil dengan anemia.

Analisis perbedaan kadar hemoglobin sebelum dan sesudah diberikan zat besi dan sayur bayam pada kelompok intervensi ibu hamil dengan anemia di Wilayah Kerja Puskesmas Martapura 1 menunjukkan analisis kadar hemoglobin sebelum dan sesudah diberikan zat besi dan sayur bayam pada kelompok intervensi dengan hasil Uji Paired T-test didapatkan nilai signifikan pengaruh yaitu 0,000 yang artinya nilai $\alpha(<0,05)$ maka dapat disimpulkan bahwa terdapat pengaruh pemberian zat besi dan sayur bayam terhadap peningkatan kadar hemoglobin.

Dalam memenuhi kebutuhan zat besi, seseorang biasanya mengkonsumsi tablet zat besi, akan tetapi salah satu alternatif untuk memenuhi kebutuhan zat besi dapat dilakukan dengan mengkonsumsi sayuran yang mengandung zat besi. Zat besi ditemukan dalam sayur-sayuran antara lain bayam. Sayuran berhijau daun seperti bayam adalah sumber besi non-heme. Bayam yang telah dimasak mengandung zat besi sebanyak 8,3 mg/100 gram. Menambahkan kandungan zat besi pada bayam berperan untuk pembentukan hemoglobin (Rohmatika, 2017).

Bayam hijau sendiri memiliki banyak manfaat yang sangat baik karena merupakan sumber kalsium, vitamin A, Vitamin C, dan Vitamin E, serat dan juga betakaroten. Selain itu bayam juga memiliki kandungan zat besi yang sangat tinggi untuk mencegah anemia. Kandungan mineral dalam bayam cukup tinggi, terutama Fe dalam 
bayam cukup tinggi ditambah kandungan vitamin B terutama asal folat (Rohmatika,2017). Peneliti berpendapat hal tersebut dikarenakan zat besi dan sayur bayam sangat membantu untuk meningkatkan kadar hemoglobin dalam darah dimana kandungan dari zat besi dan sayur bayam sangat berpengaruh untuk meningkatkan kadar hemoglobin dengan demikian mengkonsumsi zat besi dan sayur bayam dapat meningkatkan kadar hemoglobin pada ibu hamil dengan anemia karena sayur bayam adalah salah satu sayuran yang banyak mengandung zat besi sehingga mampu meningkatkan kadar hemoglobin bagi ibu hamil yang mengkonsumsinya.

Perbedaan kadar hemoglobin sebelum dan sesudah diberikan zat besi pada kelompok kontrol ibu hamil dengan anemia di Wilayah Kerja Puskesmas Martapura 1 menunjukkan analisis kadar hemoglobin sebelum dan sesudah diberikan zat besi pada kelompok kontrol dengan hasil $U j i$ Paired T-test didapatkan nilai signifikan pengaruh yaitu 0,000 yang artinya nilai $\alpha(<0,05)$ maka dapat disimpulkan bahwa terdapat pengaruh pemberian zat besi terhadap peningkatan kadar hemoglobin.

Pada ibu hamil biasanya diberikan obat tablet zat besi dosis sebanyak $60 \mathrm{mg}$ besi selama 6 bulan untuk memenuhi kebutuhan fisiologis selama kehamilan (Rohmatika, 2017). Pemberian preparat zat besi sebesar $60 \mathrm{mg}$ asam folat $0.40 \mathrm{mg}$ selama 30 hari dapat meningkatkan kadar HB sebanyak 1 gram untuk pemberian $1 \mathrm{x}$ sehari. (Saifuddin, 2010). Program pemberian tablet zat besi adalah tablet yang mengandung $60 \mathrm{mg}$ zat besi dan 0,40 asam folat yang disediakan oleh pemerintah dan dibagikan secara gratis di beberapa tatanan fasilitas pelayanan kesehatan, tempat pendidikan dan ditempat kerja (Kemenkes RI, 2016).

Dalam mengkonsumsi zat besi tidak dianjurkan dengan mengkonsumsi beberapa makanan dapat menghalangi penyerapan zat besi. Ini termasuk susu, protein kedelai, kuning telur, kopi dan teh. (Proverawati, 2013). Dengan demikian dapat kita ketahui bahwa tablet zat besi tersebut dapat meningkatkan kadar hemoglobin dalam darah asalkan mengkonsumsinya dengan benar dimana tablet zat besi yang diberikan selama 14 hari dengan mengkonsumsi $2 \mathrm{x}$ sehari dapat meningkatkan kadar hemoglobin $1 \mathrm{~g} / \mathrm{dl}$.

Analisis perbedaan kadar hemoglobin pada kelompok intervensi dan kelompok kontrol ibu hamil dengan anemia di Wilayah Kerja Puskesmas Martapura 1 analisis perbedaan kadar hemoglobin pada kelompok intervensi dan kelompok kontrol dengan hasil uji Independent $T$ test didapatkan nilai signifikan $p$-value 0,001 yang artinya nilai $\alpha(<0,05)$ maka dapat disimpulkan ada perbedaan pengaruh pada kelompok intervensi dan kelompok kontrol dalam perubahan kadar hemoglobin.

Bayam hijau memiliki banyak memiliki manfaat yang sangat baik karena merupakan sumber kalsium, vitamin A, Vitamin C, dan Vitamin E, serat dan juga betakaroten. Selain itu bayam juga memiliki kandungan zat besi yang sangat tinggi untuk mencegah anemia. Kandungan mineral dalam bayam cukup tinggi, terutama Fe dalam bayam cukup tinggi ditambah kandungan vitamin B terutama asal folat (Rohmatika,2017).

Bayam sebanyak $200 \mathrm{mg}$ diolah dengan cara direbus dengan air $500 \mathrm{ml}$, rebus air sampai mendidih baru masukan bayam, tambahkan garam $1 / 2 \mathrm{sdm}$ dan gula $1 / 4 \mathrm{sdm}$ usahakan merebus bayam jangan terlalu lama atau diperlukan waktu sekitar 3 menit dengan api sedang. Karena jika terlalu lama kandungan dalam bayam tersebut bisa hilang, bayam yang sudah dimasak dalam $100 \mathrm{mg}$ mengandung zat besi sebanyak 8,3 mg (Rohmatika, 2017). Hasil ini sejalan dengan penelitian Rohmatika, dkk (2017) mengkonsumsi zat besi ditambah ekstrak bayam hijau selama 7 hari secara teratur dapat meningkatkan kadar hemoglobin pada ibu hamil dengan anemia, kenaikan kadar hemoglobin pada pemberian 7 hari pada penelitian tersebut adalah $0,541 \mathrm{~g} / \mathrm{dl}$. Dengan demikian pemberian zat besi dan sayur bayam dapat membantu meningkatkan kadar hemoglobin pada ibu hamil dengan anemia.Ternyata pada penelitian yang dilakukan oleh peneliti untuk pemberian tablet zat besi dan sayur bayam selama 14 hari secara rutin dan benar dapat meningkatkan lebih banyak kadar hemoglobin dalam darah dibanding dengan pemberian yang hanya dilakukan selama 7 hari, pemberian 14 hari ini juga membantu agar dapat memaksimalkan peningkatan kadar hemoglobin pada ibu hamil dengan anemia. Dengan demikian dapat disimpulkan bahwa ibu hamil dengan anemia mengkonsumsi zat besi $120 \mathrm{mg}$ per hari ( $2 \mathrm{x}$ sehari) ditambah dengan sayur bayam mampu menaikan kadar hemoglobin 1,43 g/dl. 


\section{Kesimpulan}

Kadar hemoglobin sebelum dan sesudah diberikan zat besi dan sayur bayam pada kelompok intervensi dengan nilai rerata sebelum diberikan 9,55 $\mathrm{g} / \mathrm{dl}$ dan nilai rerata sesudah diberikan 10,96 g/dl. Kadar hemoglobin sebelum dan sesudah diberikan zat besi pada kelompok kontrol dengan nilai rerata sebelum diberikan 9,69 $\mathrm{g} / \mathrm{dl}$ dan nilai rerata sesudah diberikan 10,86 g/dl. Ada perbedaan kadar hemoglobin sebelum dan sesudah diberikan zat besi dan sayur bayam pada kelompok intervensi dengan hasil uji paired T-test nilai $p$-value $0,000(\alpha<0,05)$ dan terdapat rerata selisih 1,43 g/dl. Ada perbedaan kadar hemoglobin sebelum dan sesudah diberikan zat besi pada kelompok kontrol dengan hasil uji paired T-test nilai p-value $0,000(\alpha<0,05)$ dan terdapat rerata selisih $1,17 \mathrm{~g} / \mathrm{dl}$. Ada perbedaan peningkatan kadar hemoglobin pada dua kelompok (kelompok intervensi dan kelompok kontrol) dengan hasil uji independent $T$-test nilai $p$-value $0,001(\alpha<0,05)$ yang berarti pemberian zat besi dan sayur bayam lebih meningkatkan kadar hemoglobin pada ibu hamil.

Penelitian ini menyarankan agar Peneliti selanjutnya dapat melakukan penelitian lanjutan tentang jenis-jenis makanan lain yang dapat meningkatkan kadar hemoglobin. Perawat yang bertugas di Puskesmas Martapura 1 dapat menjadikan pertimbangan untuk menerapkan pemberian zat besi dan sayur bayam pada ibu hamil untuk proses peningkatan kadar hemoglobin. Selanjutnya, kepada ibu hamil yang mengalami anemia dapat mengkonsumsi zat besi dan ditambah dengan makanan tambahan berupa sayur bayam.

\section{Aknowledgment}

Terima kasih kepada manajemen dan pengurus Puskesmas Martapura 1 yang sudah mendukung pelaksanaan penelitian ini. Terima kasih juga terutama kepada Universitas Muhammadiyah Banjarmasin yang sudah mendukung penelitian ini.

\section{Daftar Pustaka}

Amin Huda Nurarif dan Hardhi Kusuma, (2015). Aplikasi Asuhan Keperawatan Berdasarkan Diagnosis Medisdan Nanda NIC-NOC. Mediaction Publishing.

Dheny Rohmatika, dkk, (2017). Efektivitas pemberian ekstrak bayam terhadap peningkatan kada hemoglobin pada ibu hamil dengan anemia ringan.

Dinas Kesehatan Kabupaten Banjar, (2019). Angka Kejadian Anemia Ibu Hamil Profil tahun 2018.

Dinas Kesehatan Kota Banjarmasin, (2019) Angka Kejadian Anemia Ibu Hamil Profil tahun 2018

Departemen Kesesehatan RI, (2010). Profil Kesehatan Indonesia. Jakarta

Dinas Kesehatan Provinsi Kalimantan Selatan. (2019), Angka Kejadian Anemia di Kalimantan Selatan, Profil tahun 2018.

Triono Soendoro, Ph. D dan Siswanto, MHP. DTM, (2017). Pedoman dan Standar Etik Penelitian dan Pengembangan Kesehatan Nasional.

Ersila, Wahyu., \& Prafitri, L. D. (2016). Efektifitas Pemberian Tablet Zat Besi Di Tambah Pepaya (Carica Papaya L.) Terhadap Peningkatan Kadar Hemoglobin Pada Remaja Putri Anemia Di STIKES Muhammadiyah Pekajangan Tahun 2016. The 4 th University Research Coloquium. ISSN:2407-9189

Fatimah, S. (2009). Studi Kadar Klorofil dan Zat Besi atau Fe pada Beberapa Jenis Bayam Terhadap Tikus Putih. Anemia. Tesis. UIN Malang. Diakses 27 februari 2018

Gay, LR, Geoffrey E, Mills and Petter Airasian, (2009), Edukation Research, Copetencies Analysis and Aplication. New Jersey. Pearson Edocation, Inc

Kementrian Kesehatan RI. (2014). Profil Kesehatan Indonesia Tahun 2013. Jakarta: Kemenkes Republik Indonesia

Kementerian Kesehatan Republik Indonesia. (2019). Profil Kesehatan Indonesia 2018. Jakarta: Kementerian Kesehatan Republik Indonesia.

Luh Mariana Wirahartari, dkk, (2019). Gambaran eritrosit anemia pada ibu hamil di RSUP Sanglah Denpasar. 
Manuaba, (2010). Pengantar Kuliah Obstetri. Jakarta:EGC

Melorys Lestari Purwaningtyas, (2017). Faktor kejadian anemia pada ibu hamil

Nelma, (2013). Analisis kadar besi (fe) pada bayam merah (iresine herbstii hook) dan bayam hijau ( amaranthus tricolor sp ) yang dikonsumsi masyarakat.

Nurasih, (2015). Efektivitas Terapi Kombinasi jus bayam jeruk sunkis-madu terhadap kadar hemoglobin pada ibu hamil dengan anemia.

Noviyanti, dkk, (2019). Pengaruh pemberian susu tempe terhadap peningkatan hemoglobin pada ibu hamil dengan anemia.

Nurhayati, dkk. (2014). Pengaruh asupan tablet zat besi terhadap kadar hemoglobin pada ibu hamil di puskemas kopelma darusallam 2014.

Nursalam, (2008). Konsep dan Penerapan Metodologi Penelitian Ilmu Keperawatan. Jakarta: Salemba Medika

Nurnia dkk. (2013). Hubungan Pola Konsumsi Dengan Status Hemoglobin Anak Sekolah Dasar Di Wilayah Pesisir Kota Makasar

Pritania Astari, dkk, (2018). Anemia Pada Ibu Hamil Serta Program 1000 hari pertama kehidupan prevalensi dan analisis faktor resiko.

Proverawati, A. (2011). Anemia dan Anemia Kehamilan. Yogyakarta : Nuha Medika

Proverawati (2013). Penyakit Anemia pada Ibu Hamil. Semarang : Cendekia Ilmu

Sokidjo Notoatmojo, (2014). Metodologi Penelitian Kesehatan, Ed. Rev. Jakarta : Rineka Cipta.

RISKESDAS, (2018). Profil Kehasetan Indonesia. Jakarta
Ratih, R. H. (2017). Pengaruh Pemberian Zat Besi (Fe) Terhadap Peningkatan Hemoglobin Ibu Hamil Anemia. Journal Of Midwifery Science Volume 1. Nomor 2. ISSN : 2579-7077

Saifuddin, Abdul B, (2009). Buku ilmu kebidanan, Jakarta : Bina Pustaka Sarwono Prawirohardjo.

Sogiyono, (2017). Metode Penelitian Kuantitatif, Kualitatif, dan R\&D. Bandung Alfabeta, CV.

M. Sopiyudin Dahlan, (2012). Statisti Untuk Kedokteran Dan Kesehatan, Jakarta: Salemba Medika - Buku Cetakan Kedua

Susan C. Smeltzer, (2016). Keperawatan Medikal Bedah (Handbook For Brunner \& Sudarth's Texsbook of Medical-Surgical Nursing) Edisi . 12 . Penerbit Buku Kedokteran : EGC

Sulistyawati, Ari. (2013). Asuhan Kebidanan pada Masa Kehamilan. Cetakan kelima, Jakarta : Salemba Medika.

Sulistyoningsih, (2011). Gizi dan Kesehatan Ibu dan Anak. Yogyakarta: Graha Ilmu

Waryana. (2010). Gizi Reproduksi. Yogyakarta : Pustaka Rihami

Wahyu Nuraisa, (2018). Deteksi resiko tinggi kehamilan pada pelayanan ANC terpadu di puskesmas benso kabupaten Kediri.

Yanis, A. (2014). Hubungan Aktivitas Fisik Terhadap Kadar Hemoglobin Pada Mahasiswa Anggota UKM Pandekar Universitas Andalas. Jurnal Kesehatan Andalas Volume 3, Nomor 2

Yanti,D, Sulistianingsih A., dan Keisnawati 015 (2018). Faktor-Faktor Terjadinya Anemia Pada Ibu Primigravida Diwilayah Kerja Puskesmas Pringsewu Lampung.Jurnal Keperawatan STIKes Muhammadiyah pringsewu lampung.Vol 6.No.2.Lampung. 